\title{
The impact of the education level of the members who benefit from sports businesses on their service quality expectation and perception level
}

\author{
Havva DEMIREL, Metin YAMAN \\ ${ }^{1}$ Physical Education and Sports,Selcuk University, Konya, Turkey (e-mail: havvademirel@selcuk.edu.tr). \\ ${ }^{2}$ Physical Education and Sports, Gazi University, Ankara, Turkey.
}

\begin{abstract}
This study was carried out to identify the perceptions and expectations of the members regarding the service they receive at the businesses that offers recreational sports/fitness program and to determine whether their expectations and perceptions on the service quality differ correlating with the members' level of education. Research was carried out with 623 members, 349 women, 274 men, benefiting from sports enterprises operating in the province of Ankara. The research data were obtained using "Turkish Version of the Service Quality Assessments Scale" (SQAS-T) developed by Lam et al. and tested for the reliability and validity in Turkey by Gurbuz. In data analysis, " $\mathrm{t}$ " and "ANOVA" tests were used in independent groups. The expected service quality scores of the members whose education level was high school were determined to be significantly higher $(\mathrm{p}<0.05)$ only in terms of staff than the members whose education level was university, but there were no differences $(p>0.05)$ in the other sub-dimensions. Also according to the education level of the members who participated in the research statistically meaningful differences $(\mathrm{p}<0.05)$ were determined between the perceived service quality scores in terms of the staff, program, dressing rooms, and the institution. In conclusion, the level of education was determined to have an impact on expected and perceived service quality.
\end{abstract}

Key words: Sports business, service quality, expectations, perceptions.

\section{INTRODUCTION}

The recreational sports consciousness is a phenomenon that is growing rapidly across the world. Technological advances and the increase in the level of welfare of the people, naturally, feature the importance of the service sector day by day. In industrialized countries, as working and nonworking time has an order, recreational sports activities have an important role in leisure activities that working people can participate actively or passively to be able to refresh physically and mentally (10).

Recreational sport is the sports activities that individuals do in sports centers or outdoor spaces to be healthy, and provide physical, mental, spiritual, and social benefits, either by paying money or without paying (4).

In the study it has been concluded that customers' expectations about the service can be at two distinct levels. These are "expected" and "perceived" level of service (8). Research on quality of service has been observed to increase especially in United States and the Scandinavian countries since 1980 (13). To the present, many models have been developed to measure the quality of service. With these models many studies have been done to measure the quality of service (2). They stated stat the quality of service depends on customer's subjective perception about his/her experiences and mentioned items would wary from person to person (16).

The various interactions that occur between the costumer and business personnel during the presentation of the service are evaluated within the scope of functional quality (20). While the sports programs in public sports centers are offered as a public service, subsidizing because of the inability to finance the business, burdens largely on public finances (7). The concept of quality is expanding its scope and growing in importance depending on the degree of its impact on the society and the human element of society (17). 
Recreational sports at the same time help the development and organization of an individual's mental health, aim to develop his/her life and make it meaningful, make the individual efficient and improves the efficiency by giving new knowledge and skills (19).

Whether the goods or the service production is in question, when the term quality is pronounced four dimensions, that are design quality (preproduction quality), quality of conformance (respond to the need), product features and aftersales services (field service), come to mind and all of these dimensions are equally important to the success of business activities (16).

This study was carried out to identify the perceptions and expectations of the members regarding the service they receive at the businesses that offers recreational sports/fitness program and to determine whether their expectations and perceptions on the service quality differ correlating with the members' level of education.

\section{MATERIAL \& METHODS}

\section{Research Sample}

Research was carried out with 623 volunteer members, 349 women, 274 men, benefit from special sports enterprises that offer recreational sports/fitness program, in the province of Ankara.

\section{Data Collection Method}

The research data were obtained using "Turkish Version of the Service Quality Assessments Scale" (SQAS-T) developed by Lam et al. (12) and tested for the reliability and validity in Turkey by Gurbuz (8). For data analysis SPSS 16.0 statistical packet programme was used. The data was tested for normal distribution with One-Sample Kolmogorov-Smirnov test. To study the difference among the independent variables IndependentSample $\mathrm{T}$ test and ANOVA test was used. The reasons of the differences according to the independent variables were studied with multiple comparison test- Tukey test. The error level was taken as 0,05 .

Service Quality Assessment Scale consists of 5 sub-dimensions and 40 items. These sub-dimensions are staff (9 items), program (7 items), dressing room (5 items), plants (13 items), and child care (6 items). Four of five sub-dimensions were used in this study. The scale is Likert-type and its rating is between 1 (least important) to 7 (very important) in the dimension of expected service; from 1 (poor) to 7 (excellent) in the dimension of perceived service.

\section{Statistical Analysis}

One-Sample Kolmogorov-Smirnov Test was used to see whether the data show a normal distribution or not. Because the data showed a normal distribution, the Independent-sample t-test and ANOVA test were used to identify the differences between the independent variables. The sources of the differences between the independent variables were determined by Tukey test, which is one of the multiple comparison tests. In this study, the error level was adopted as 0.05 .

\section{RESULTS}

While statistically significant differences $(\mathrm{p}<0.05)$ were detected between the scores of expected service quality in terms of the staff and the program according to the education level of the members (Table 1), no significant differences $(p>0.05)$ were detected between the scores of the service quality for the dressing rooms and the institution. The expected service quality scores of the members whose education level was high school were determined to be significantly higher $(p<0.05)$ only in terms of staff than the members whose education level was university, but there were no differences $(p>0.05)$ in the other sub-dimensions.

Also according to the education level of the members who participated in the research, statistically meaningful differences $(p<0.05)$ were determined between the perceived service quality scores in terms of the staff, program, dressing rooms, and the institution (Table 2).

The perceived service quality scores of the members whose education level was high school were determined to be significantly higher $(p<0.05)$ in terms of the staff, program, dressing rooms, and the institution, than the members whose education level was university but the perceived service quality scores of the members whose education level was primary school were determined to be significantly higher $(\mathrm{p}<0.05)$ only in terms of the institutions than the members whose education level was university. 
Table 1. Multiple comparisons of the expected service quality and the education level of the members that participated in the study.

\begin{tabular}{|c|c|c|c|c|c|}
\hline Variables & (I) education & (J) education & Mean difference (I-J) & Std. error & $\mathrm{P}$ \\
\hline \multirow{9}{*}{ Staff } & \multirow{3}{*}{ Primary School } & Secondary School & 0,712 & 1,280 & 0,945 \\
\hline & & High School & $-1,570$ & 1,005 & 0,401 \\
\hline & & University & 1,135 & 0,968 & 0,644 \\
\hline & \multirow{3}{*}{ Secondary School } & Primary School & $-0,712$ & 1,280 & 0,945 \\
\hline & & High School & $-2,282$ & 1,071 & 0,145 \\
\hline & & University & 0,423 & 1,036 & 0,977 \\
\hline & \multirow{3}{*}{ High School } & Primary School & 1,570 & 1,005 & 0,401 \\
\hline & & Secondary School & 2,282 & 1,071 & 0,145 \\
\hline & & University & $2,705^{*}$ & 0,668 & $0,000^{*}$ \\
\hline \multirow{9}{*}{ Program } & \multirow{3}{*}{ Primary School } & Secondary School & 0,092 & 0,988 & 1,000 \\
\hline & & High School & $-0,709$ & 0,775 & 0,797 \\
\hline & & University & 1,016 & 0,747 & 0,525 \\
\hline & \multirow{3}{*}{ Secondary School } & Primary School & $-0,092$ & 0,988 & 1,000 \\
\hline & & High School & $-0,801$ & 0,827 & 0,767 \\
\hline & & University & 0,925 & 0,800 & 0,655 \\
\hline & \multirow{3}{*}{ High School } & Primary School & 0,709 & 0,775 & 0,797 \\
\hline & & Secondary School & 0,801 & 0,827 & 0,767 \\
\hline & & University & $1,726^{*}$ & 0,515 & $0,005^{*}$ \\
\hline
\end{tabular}

${ }^{*} \mathrm{P}<0.05$

Table 2. Multiple comparisons of the perceived service quality and the education level of the members that participated in the study.

\begin{tabular}{|c|c|c|c|c|c|}
\hline Variables & (I) education & (J) education & Mean difference (I-J) & Std. error & $\mathrm{P}$ \\
\hline \multirow{9}{*}{ Staff } & \multirow{3}{*}{ Primary School } & Secondary School & $-0,289$ & 1,300 & 0,996 \\
\hline & & High School & $-0,896$ & 1,021 & 0,817 \\
\hline & & University & 1,457 & 0,984 & 0,450 \\
\hline & \multirow{3}{*}{ Secondary School } & Primary School & 0,289 & 1,300 & 0,996 \\
\hline & & High School & $-0,607$ & 1,089 & 0,944 \\
\hline & & University & 1,746 & 1,053 & 0,347 \\
\hline & \multirow{3}{*}{ High School } & Primary School & 0,896 & 1,021 & 0,817 \\
\hline & & Secondary School & 0,607 & 1,089 & 0,944 \\
\hline & & University & $2,353^{*}$ & 0,679 & $0,003^{*}$ \\
\hline \multirow{9}{*}{ Program } & \multirow{3}{*}{ Primary School } & Secondary School & $-0,180$ & 1,055 & 0,998 \\
\hline & & High School & $-0,771$ & 0,827 & 0,788 \\
\hline & & University & 1,149 & 0,798 & 0,475 \\
\hline & \multirow{3}{*}{ Secondary School } & Primary School & 0,180 & 1,055 & 0,998 \\
\hline & & High School & $-0,591$ & 0,882 & 0,908 \\
\hline & & University & 1,329 & 0,854 & 0,405 \\
\hline & \multirow{3}{*}{ High School } & Primary School & 0,771 & 0,827 & 0,788 \\
\hline & & Secondary School & 0,591 & 0,882 & 0,908 \\
\hline & & University & $1,920^{*}$ & 0,549 & $0,003^{*}$ \\
\hline \multirow{9}{*}{ Dressing Rooms } & \multirow{3}{*}{ Primary School } & Secondary School & 0,362 & 0,965 & 0,982 \\
\hline & & High School & $-1,364$ & 0,757 & 0,274 \\
\hline & & University & 0,392 & 0,730 & 0,950 \\
\hline & \multirow{3}{*}{ Secondary School } & Primary School & $-0,362$ & 0,965 & 0,982 \\
\hline & & High School & $-1,725$ & 0,807 & 0,142 \\
\hline & & University & 0,031 & 0,781 & 1,000 \\
\hline & \multirow{3}{*}{ High School } & Primary School & 1,364 & 0,757 & 0,274 \\
\hline & & Secondary School & 1,725 & 0,807 & 0,142 \\
\hline & & University & 1,756 & 0,503 & $0,003^{*}$ \\
\hline \multirow{9}{*}{ Staff } & \multirow{3}{*}{ Primary School } & Secondary School & 0,926 & 1,953 & 0,965 \\
\hline & & High School & $-0,900$ & 1,532 & 0,936 \\
\hline & & University & 4,530 & 1,477 & $0,012^{*}$ \\
\hline & \multirow{3}{*}{ Secondary School } & Primary School & $-0,926$ & 1,953 & 0,965 \\
\hline & & High School & $-1,825$ & 1,633 & 0,679 \\
\hline & & University & 3,604 & 1,582 & 0,104 \\
\hline & \multirow{3}{*}{ High School } & Primary School & 0,900 & 1,532 & 0,936 \\
\hline & & Secondary School & 1,825 & 1,633 & 0,679 \\
\hline & & University & 5,430 & 1,017 & $0,000^{*}$ \\
\hline
\end{tabular}




\section{DISCUSSION}

In our study, in terms of staff, the expected service quality scores of the members whose education level was high school were determined to be higher than the members whose education level was university (3). In the study investigating the association between the level of education and the expected service quality, in the sub-dimension of the staff, the service quality scores of the members with high school education level were determined higher than the members with other education levels. Boz's these results are parallel with our study. They obtained different results from our study, in their research on the expected service quality of the members who received fitness services (6).

In another research, it is seen that, the members who had been benefiting from the institutions for 1 year and longer, concluded that the continuity of the service quality decreased over time (1).

Various research results have shown that perceived service quality has a positive impact on customer satisfaction. Therefore, the institutions offering recreational sports/fitness program, who want to create customer continuity, must give place to the properties, methods, and practices that affect both perceived service quality and customer satisfaction (9). In other studies, it is emphasized that, the ease of transportation is one of the most important factors in the preference of the sports centers (14). Nowadays, many sports business are competing to gain customers and to please their customers by offering "quality service". The criteria for determining the success of a sports business is the quality of the service offered to the customers (11).

The expected service quality scores of the members with university education level were found to be higher than the other education levels. Results indicate that, the higher the level of the education of the members, the higher their quality of service expectations. They interpreted that it would be because the members with university level education received better education, and because they could communicate with the staff more easily and effectively $(6,21)$.

In Portugal, an investigation was done in the sports clubs in order to measure customer satisfaction and to compare with the demographic factors, and according to the findings of this study, statistically significant differences in terms of the institution were found in line with gender. Higher scores were obtained from males in terms of institutions. That is, women seem to be less satisfied than men with the service (18).

In conclusion, in this study, the level of education was determined to have an impact on expected and perceived service quality. In this context, only the members with high school education level were found to have higher expectations and perceptions in the staff and program subscales, compared to other education levels.

\section{REFERENCES}

1. Akbaba A. Konaklama İsletmelerinde Kalite Fonksiyon Göçerimi, D.E.Ü. Sosyal Bilimler Enstitüsü, Yayımlanmamış Doktora Tezi, İzmir, 2003.

2. Ardıç K, Baş T. Saglık Sektöründe Hizmet Kalitesinin (Müşteri Tatmininin) Ölçülmesi (Sakarya Doğum ve Çocuk Bakımevi Hastanesinde Bir Uygulama), (Www.Geocities.Com/Ceteris_Paribus_Tr/Ardic8.Doc (Tarihi: 30.04.2007), 2001; S.4.

3. Boz C. Yerel Yonetimlerin Spor Tesislerinde Toplam Kalite Yönetimi Uygulamaları, (İstanbul Büyüksehir Belediyesi Örneği), Marmara Universitesi,Yuksek Lisans Tezi,İstanbul, 2007

4. Brady M.K, Cronin J. J. Some new thoughts on conceptualizing perceived service quality: a hierarchical Approach, Journal of Marketing, 2001; 65: 34- 49.

5. Caruana A, Ewing MT, Ramaseshan B. Assessment of the Three-Column Format SERVQUAL: An experimental approach. Journal of Business Research, 2000; 49, pp.57 65.

6. Ceyhun S. Spor İşletmelerinde Hizmet Kalitesi, Doktora Tezi, Gazi Üniversitesi, Ankara, 2006.

7. Ekenci G. Gözen M. Türkiyede Spor Tesis ve Hizmetlerinin Özelleştirilmesi. Besbd, 2000; 5(2): 77.

8. Gürbüz B. Reliablity and Validity of the Turkish Version of the Service Quality Assessment Scale. Orta Dogu Teknik Üniversitesi. Yüksek Lisans, Ankara, 2003.

9. Gürbüz E, Büyükkeklik A, Avcılar MY, Toksari M. Alg1lanan hizmet kalitesinin tatmin ve davranışsal niyet üzerine etkisi, Niğde ilindeki süpermarketler üzerine ampirik bir çalışma. Ege Akademik Bakis: 2008; 8(2): 785-812.

10. Karaküçük S. Rekreasyon Boş Zamanları Degerlendirme, Gazi Kitabevi, Ankara. 2005; 5. Bask1, S.48.

11. Ko YJ, Pstore DL. A Hierarchical Model Of Service Quality Fort He Recreational Sport Industry. Sport Marketing Quarterly, 2005; 14(2): 84-97.1.

12. Lam ETC, Zhang JJ, Jensen BE. Service Quality Assessment Scale (SQAS): An Instrument for Evaluating Service Quality of Health- Fitness Clubs. Measurement in Physical and Exercise Science, 2005; 9(2): 79-111. 
13. Lehtinen U, Lehtinen J.R. Two Approaches to Service Quality DimensionsThe Service Industries Journal. . 1991; Vol.11, No.3. Ss.287-303.

14. Memiş UA, Ekenci G. Spor Merkezlerinde Müşteri Memnuniyeti (Ankara İli Örneği). Gazi BESBD 2007; 12(1):3348.

15. Uyguç N. Hizmet Sektöründe Kalite Yönetimi, Dokuz Eylül Yayinlari, İzmir, 1998.

16. Schroeder R. G. Operations Management: Decision Making in The Operations Function. Mcgraw-Hill: New York. 1993.

17. Tekin M. Toplam Kalite Yonetimi, Seckin Basın Yayın Dagitım. Ankara: 2004; 3. Bask1.
18. Theodorakıs N, Alexandris K, Rodriguez P, Sarmento Pj. Measuring Customer Satifaction İn The Context Of Health Clubs İn Pottugal International Sports Journal. Winter; 2004; 8(1):44-53

19. Yetim A. Sosyoloji ve Spor, Topkar Matbaacıllk, Ankara. 2000; S.167

20. Yılmaz İ. Otel İşletmelerinde Hizmet Kalitesinin Müşteriler ve Yöneticiler Açısından Ölçülmesi, Dokuz Eylul Universitesi, Sosyal Bilimler Enstitüsü Turizm İşletmeciliği Anabilimdali, Turizm İşletmeciliği Programı, Doktora Tezi 2007.

21. Yüzgenç A. Yerel Yönetimlerin Sunduğu Spor Hizmetlerinde Hizmet Kalitesi, Gazi Üniversitesi, Yüksek Lisans. Ankara, 2010. 